\title{
Ventriculoperitoneal Shunt-related Intrapelvic Abscess
}

\author{
Takahiro Zenda ${ }^{1}$, Emi Sawada ${ }^{2}$ and Ichiro Araki ${ }^{1}$
}

Key words: ventriculoperitoneal shunt-related abscess, cerebrospinal fluid-filled pseudocyst, skewered dumpling-like appearance

(Intern Med 59: 1017-1018, 2020)

(DOI: 10.2169/internalmedicine.3908-19)

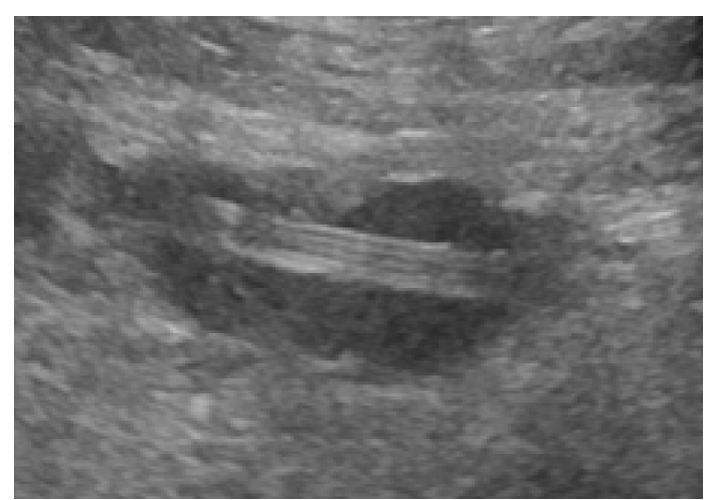

Picture 1.

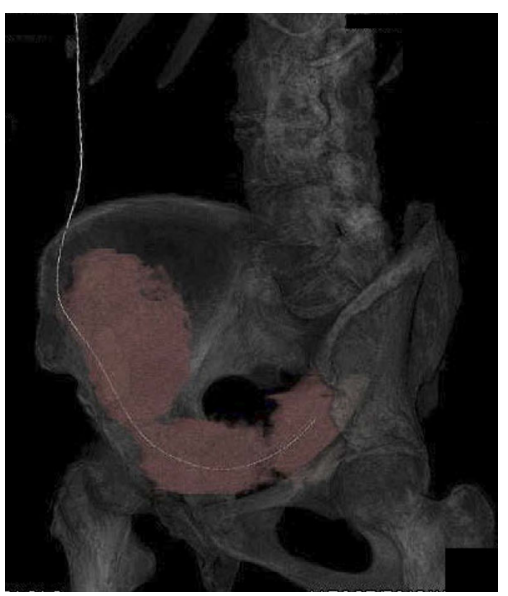

Picture 3.

A 74-year-old woman with a 12-year history of ventriculoperitoneal shunt implantation presented with a high fever. Neither neurological symptoms nor vital signs except for a fever of $38.2^{\circ} \mathrm{C}$ were remarkable; a physical examination indicated mild lower abdominal bulging without tenderness. A blood examination revealed an elevated C-reactive protein level (15.48 mg/dL) but normal white blood cell counts. Ab-

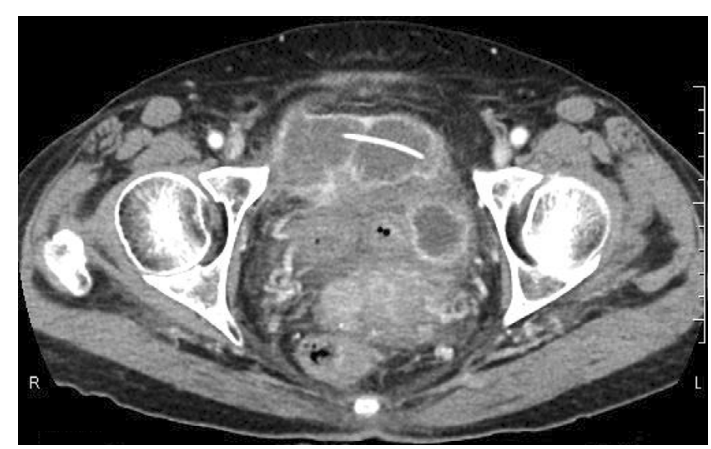

Picture 2.

dominopelvic ultrasonography (Picture 1) and contrastenhanced computed tomography (Picture 2) including threedimensional image reconstruction (Picture 3) revealed a well-defined, lobulated, fluid-filled structure, circumferentially surrounding and spreading along the route of the catheter, suggesting an intrapelvic abscess. To prevent retrograde life-threatening infectious sequelae, shunt removal and open drainage were immediately performed. Culturing of the drained pus yielded $\alpha$-Streptococcus and Escherichia coli, but such findings of the removed catheter were negative. The postoperative recovery was uneventful. Physicians should be aware of the characteristic features of abscess associated with ventriculoperitoneal shunt, which can develop via secondary infection of the cerebrospinal fluid-filled pseudocyst $(1,2)$, presenting with a skewered dumpling-like appearance.

The authors state that they have no Conflict of Interest (COI).

\section{References}

1. Rinker EK, Williams TR, Myers DT. CSF shunt complications: what the abdominal imager needs to know. Abdom Imaging 40: 2030-2040, 2015.

\footnotetext{
${ }^{1}$ Department of Internal Medicine, Asanogawa General Hospital, Japan and ${ }^{2}$ Department of Radiology, Asanogawa General Hospital, Japan
} Received: September 10, 2019; Accepted: October 17, 2019; Advance Publication by J-STAGE: November 29, 2019 Correspondence to Dr. Takahiro Zenda, zenda@asanogawa-gh.or.jp 
2. Kashyap S, Ghanchi H, Minasian T, Dong F, Miulli D. Abdominal pseudocyst as a complication of ventriculoperitoneal shunt placement: Review of the literature and a proposed algorithm for treatment using 4 illustrative cases. Surg Neurol Int 8: 78, 2017.
The Internal Medicine is an Open Access journal distributed under the Creative Commons Attribution-NonCommercial-NoDerivatives 4.0 International License. To view the details of this license, please visit (https://creativecommons.org/licenses/ by-nc-nd/4.0/).

(C) 2020 The Japanese Society of Internal Medicine Intern Med 59: 1017-1018, 2020 